УДК 631.467:574.42:504.5:622.276(985)

doi: 10.31140/J.VESTNIKIB.2019.1(208).2

\title{
ВОССТАНОВЛЕНИЕ КОМПЛЕКСОВ ПОЧВЕННЫХ БЕСПОЗВОНОЧНЫХ ПОСЛЕ НЕФТЯНОГО ЗАГРЯЗНЕНИЯ: ВЛИЯНИЕ СОСТАВА И СТЕПЕНИ РАЗВИТИЯ РАСТИТЕЛЬНОГО СООБЩЕСТВА
}

\author{
Е.Н. Мелехина \\ Институт биологии Коми научного центра Уральского отделения Российской академии наук, Сыктывкар \\ E-mail: melekhina@ib.komisc.ru
}

\begin{abstract}
Аннотация. Выявлено повышение плотности населения беспозвоночных в ряду сукцессии фитоценоза «без растений» - «низкое проективное покрытие» - «высокое проективное покрытие» после рекультивации загрязненной нефтью торфяной почвы. На ранней стадии сукцессии («без растений») группировки животных были представлены небольшим числом таксонов; доминирующими по обилию были мезостигматические клещи и личинки двукрылых. На стадии сукцессии «низкое проективное покрытие» увеличивалось разнообразие микроартропод, в составе группировок отмечались акаридиевые и простигматические клещи. На стадии "высокое проективное покрытие» наблюдался всплеск численности коллембол, которые становились доминирующей группой. Панцирные клещи регистрировались в почве позже других групп беспозвоночных; их разнообразие повышалось на более поздних стадиях развития фритоценоза - постепенного замещения сеяных злаков аборигенными растениями.
\end{abstract}

Ключевые слова: нефтяное загрязнение, почвенные беспозвоночные, панцирные клещи (Oribatida), мезостигматические клещи (Mesostigmata), простигматические клещи (Prostigmata), акаридиевые клещи (Acaridia), коллемболы (Collembola), личинки двукрылых (Diptera), биорекультивация, подзона крайнесеверной тайги

\section{Введение}

Нефтяное загрязнение - значимый для европейской Субарктики фактор нарушения природных сообществ. В зоне деятельности предприятий нефтедобывающей и нефтеперерабатывающей промышленности происходят аварийные разливы нефти, которые оказывают отрицательное воздействие на почвенную биоту. С целью восстановления нарушенных экосистем применяют различные способы рекультивации (Маркарова, 1999, 2004). Изучение особенностей демутации загрязнённых нефтью почвенных сообществ имеет практическое значение для диагностики их состояния и оценки әффективности рекультивационных мероприятий.

В ряде исследований показаны закономерности восстановления растительных сообществ на территориях с нефтяным загрязнением. Так, И.И. Шилова $(1977,1978)$ выделила четыре стадии сукцессии растительности на техногенных песчаных обнажениях вблизи нефтяных скважин в Тюменской области. Для первой стадии были характерны единичные пионерные растения, около $50 \%$ из них относились к сорным. В ходе сукцессии отмечено повышение общего проективного покрытия: 1-5 \% на первой, 30 - на второй, 50 - на третьей и 80-90\% - на четвёртой стадии.

Одним из этапов рекультивационных работ является фитомелиорация: посев многолетних и однолетних трав, устойчивых к нефтяному загрязнению (Природоохранные ..., 2006). На участках рекультивации развиваются растительные сообщества на основе сеяных трав, которые со временем трансформируются в фитоценозы, близкие к естественным (Канев, 2016).
Были исследованы закономерности восстановления почвенной фауны после нефтяного загрязнения (Артемьева, 1988, 1989; Жиивотное ..., 2004; Маркарова, 2006; Мелехина, 2007; Secondary successions ..., 2015). Процесс демутации рассматривали с точки зрения сукцессии; определена стадийность восстановления зооценоза (Михеева, 2008; Мелехина, 2012). Параметры разнообразия микроартропод были предложены для использования в комплексном мониторинге экосистем с нефтяным загрязнением (Определение эффективности ..., 2016; Approaches ..., 2016). Показана связь сукцессии комплексов почвенных беспозвоночных с техногенной сукцессией растительности (Артемьева, 1988, 1989). Влияние состава и структуры растительного сообщества на состав и численность микроартропод отмечено как для естественных, так и нарушенных сообществ высокой Арктики (Coulson, 2003; Microarthropod ..., 2015).

Цель настоящей работы - проследить динамику состава и структуры комплексов микрофауны в ходе сукцессии растительного сообщества в условиях нефтяного загрязнения.

\section{Материалы и методы}

Исследования проведены в Усинском районе Республики Коми. Район исследований расположен в подзонах лесотундры и крайнесеверной тайги (Юдин, 1954; Леса Республики Коми, 1999). Тип климата - умеренно-континентальный. Среднегодовая температура составляет $-4{ }^{\circ} \mathrm{C}$; средняя температура января от -18 до $-20{ }^{\circ} \mathrm{C}$, июля $+14{ }^{\circ} \mathrm{C}$. Снежный покров удерживается 210 дней в году с третьей декады октября до начала июня (Атлас Республики Коми ..., 1997). Основная часть территории района относится к Печоро-Усинскому 


\section{ВЕСТНИК ИБ КОМИ НЦ УрО РАН 2019 № 1}

округу болотно-подзолистых, глееподзолистых, тундрово-болотных и болотных торфяных почв (Атлас почв Республики Коми, 2010). Полевой сбор материала проведен на опытном участке (№ 20) в зоне деятельности ТПП «ЛУКОЙЛ-Усинскнефтегаз" на территории Возейского нефтяного месторождения (66 $37^{\prime} 40^{\prime \prime}$ с.ш., $57^{\circ} 07^{\prime} 56^{\prime \prime}$ в.д.). Почвы участка - торфяно-болотные верховые (Fibric Histosols (Dystric) с водозастойным режимом техногенно нарушенного ландшафта (Природоохранные ..., 2006).

Аварийный разлив нефти произошел в 1996 г. Слой торфа был пропитан нефтью на глубину 1.01.5 м. В 2002 г. был заложен полевой эксперимент по оценке әффективности различных методов рекультивации. Содержание нефти в почве опытных площадок перед началом рекультивации составляло от 87 до 165 мг/г (Природоохранные..., 2006). На всех опытных площадках проведена техническая рекультивация: частичное осушение с помощью дренажных каналов и сбор нефти, фрезерование почвы на глубину 3040 см. В почву двух площадок, кроме того, были внесены биопрепараты «Универсал» и «Родер» и минеральные удобрения. На площадке «агрохимические ме'оды» проведено внесение минеральных удобрений и доломитовой муки. В комплекс мероприятий рекультивации входил посев многолетних трав: на площадке “Универсал» - щучки дернистой (Deschampsia caespitosa), на площадке «Родер» - двукисточника тростникового (Phalaroides arundinacea) и тимофеевки луговой (Phleum pratense), на площадке «агрохимические методы" - многолетней травосмеси и овса посевного (Avena sativa) (Природоохранные ..., 2006). В качестве контрольной выступала площадка технической рекультивации, на которой посев трав не проводили, биопрепараты и удобрения не вносили. Фоновое растительное сообщество - ивовоерниковое осоково-хвощевое болото с торфяноболотной почвой (Определение эффективности ..., 2016).

Была выявлена определенная последовательность развития растительных сообществ на площадках рекультивации (Secondary successions ..., 2015; Канев, 2016; Определение эффективности ..., 2016). Для ранних стадий сукцессии фитоценоза было характерно низкое проективное покрытие травяного яруса, преобладание пионерных сорных растений, таких как трехреберник непахучий (Tripleurospermum perforatum), бородавник обыкновенный (Lapsana communis), иванчай узколистный (Chamaenerion angustifolium), щавель кисловатый (Rumex acetosella) и др. Coобщество при этом было развито мозаично. В ходе сукцессии формировались сообщества из сеяных злаков, увеличивалось их общее проективное покрытие. На более поздних стадиях сукцессии происходило постепенное выпадение сеяных трав и замена их видами местной флоры (злаками, осоками, пушицами); развивался моховой покров, появлялись кустарнички и древесные растения.

Через четыре года после рекультивации (2006 г.) на опытных площадках были развиты растительные сообщества с преобладанием высеянных злаков. На площадке «Родер» - злаковое сообщество, общее проективное покрытие травянистого яруса (ОПП) 70-80 \% с доминированием тимофеевки луговой и двукисточника тростникового. Сообщество площадки «Универсал» - щучковоразнотравное, ОПП 90-95 \%; доминирующий вид - щучка дернистая с проективным покрытием 60-70\%. На площадке "агрохимические методы» - злаково-разнотравное сообщество с ОПП 30-40\%, местами наблюдалось высокое проективное покрытие (до 70 \%) тимофеевки луговой. Через семь лет (2009 г.) в составе фитоценозов продолжали доминировать высеянные злаки, сохранялась мозаичность растительного покрова (Secondary successions ..., 2015; Канев, 2016; Определение эффективности ..., 2016).

По степени развития растительного сообщества на каждой площадке рекультивации были выделены сходные стадии сукцессии фитоценоза, отличающиеся общим проективным покрытием травяного яруса. В качестве самой ранней стадии сукцессии была определена стадия «без растений». Для стадии «низкое проективное покрытие» было характерно общее проективное покрытие 30-40\%, для стадии «высокое проективное покрытие» - 70-80 \%. Все указанные стадии сукцессии присутствовали на площадках «Универсал», "Родер", «агрохимические методы». Для контрольной площадки (техническая рекультивация) была характерна стадия «без растений». На стадии «высокое проективное покрытие» были изучены группировки беспозвоночных под разными видами злаков-рекультивантов: тимофеевкой луговой и двукисточником тростниковым на площадке «агрохимические методы», тимофеевкой луговой на площадке «Родер», тимофеевкой луговой и щучкой дернистой на площадке «Универсал".

Пробы на микрофауну отобраны в августе 2006 и 2009 гг. в 12-кратной повторности на каждой опытной площадке размером $5 \times 5$ см (площадью $0.0025 \mathrm{~m}^{2}$ ), глубиной 10 см. Извлечение беспозвоночных из почвенных проб осуществляли стандартным методом - с помощью термоэклекторов Берлезе-Тульгрена. Учитывали всех представителей размерно-функциональной группы микрофауны - животных размерами от 0.1 до 2-3 мм: мезостигматических, простигматических, акаридиевых, панцирных клещей, коллембол, мелких личинок двукрылых, жесткокрылых. Таксономия орибатид приведена в соответствии с Subias, 2001, online version in march 2019. Основными параметрами, по которым проводили сравнение груп- 
пировок беспозвоночных на разных стадиях сукцессии фитоценоза, были плотность населения животных, экз. $/ \mathrm{M}^{2}(\mathrm{Me}-$ тоды ..., 1975) и относительное обилие таксонов в процентах (Песенко, 1982). Первичную статистическую обработку данных проводили в программе Microsoft Excel 2010. В качестве показателя варьирования значений плотности беспозвоночных использовали ошибку средней. Достоверность различий плотности населения микроартропод определяли с помощью непараметрического критерия Манна-Уитни при уровне значимости $\mathrm{p}<$ 0.05 в программе PAST V 3.0 (Hammer, 2001).

Результаты и обсуждение

Численность, состав и структура населения почвенных беспозвоночных изменялись с определенной закономерностью в ряду восстановительной сукцессии фитоценоза.

Плотность населения. Через четыре года после рекультивации (2006 г.) на опытной площадке «агрохимические методы» наиболее высокая плотность населения беспозвоночных была зарегистрирована на стадии "высокое проективное покрытие» под злаками тимофеевкой луговой и двукисточником тростниковым, статистически отличаясь (при р < 0.05) от стадии «без растений» и контрольной площадки (механическая уборка нефти) (рис. 1, А). На площадке «Универсал» наиболее высокие абсолютные значения плотности отмечены в почве под щучкой дернистой. Статистически отличались друг от друга стадии «низкое проективное покрытие», «без растений», контроль и один из злаков - тимофеевка луговая (рис. 1, В). На площадке «Родер» плотность населения микроартропод под тимофеевкой была статистически выше, чем на стадии «низкое проективное покрытие» и на контрольной площадке, и не отличалась статистически от фоновой (рис. $1, \mathrm{C})$. Абсолютные значения плотности на площадке «Родер» под злаками были на порядок выше, чем в подобных группировках площадок «Универсал» и «агрохимические методы», а также в фоновом сообществе. На контрольной площадке (техническая рекультивация) плотность населения беспозвоночных была ниже (5400 экз. $/ \mathrm{M}^{2} ; \mathrm{p}<$ 0.05), чем на площадках биорекультивации под сеяными злаками и на фоновом участке. В фоновом ивово-ерниковом осоково-хвощевом сообществе этот показатель достигал 64800 экз. $/ \mathrm{M}^{2}$.
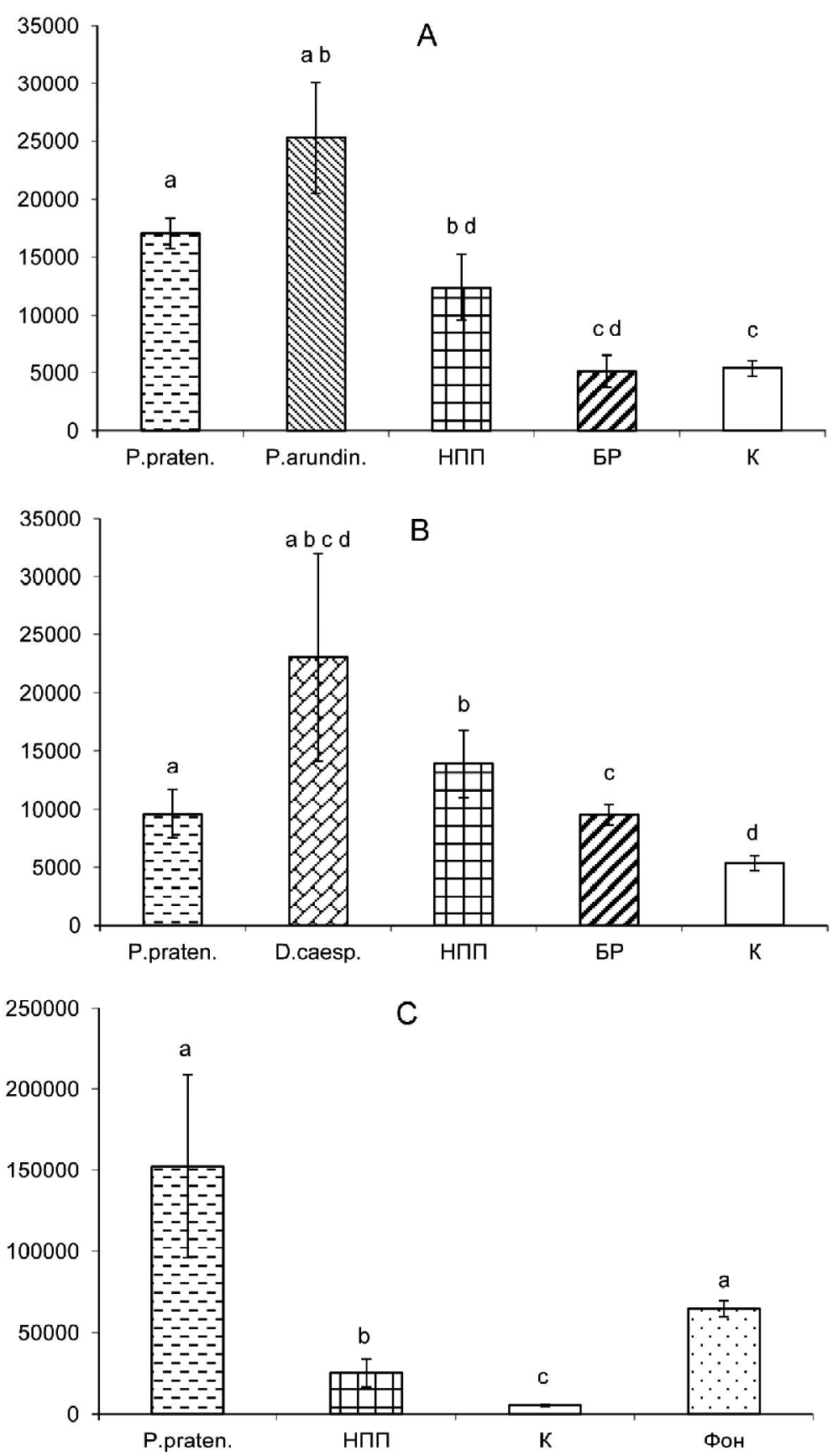

Рис. 1. Плотность населения (экз./M², по вертикали; показана ошибка средней) беспозвоночных на разных стадиях сукцессии фитоценоза и под разными злаками (К - контроль, БР - без растений, НПП - низкое проективное покрытие, P. praten. - Phleum pratense, D. caesp. - Deschampsia caespitosa, P. arundin. - Phalaroides arundinacea). Опытные площадки: А - «агрохимические методы», В - «Универсал», C - «Родер»; 2006 г. (буквами а, b, с и d показана достоверность различий параметра при $\mathrm{p}<0.05)$.

В целом можно заключить, что в ряду сукцессии фитоценоза «без растений» - «низкое проективное покрытие» - «высокое проективное покрытие» было зарегистрировано повышение плотности населения беспозвоночных.

Динамика обилия таксонов беспозвоночных. В ходе сукцессии фитоценоза изменялось обилие отдельных таксонов беспозвоночных, соответственно, менялся их вклад в структуру группировок. 
Mesostigmata. Доля мезостигматических клещей в структуре населения наиболее высокой была на ранних стадиях сукцессии. Так, в первый период наблюдений плотность населения Mesostigmata была статистически выше, чем всех остальных групп, на контрольной площадке (стадия «без растений») (рис. 2, А). Через семь лет после рекультивации отмечено снижение плотности населения мезостигматических клещей на стадии сукцессии фитоценоза «высокое проективное покрытие» как при агрохимической обработке почвы, так и на площадках с применением биопрепаратов. Под злаками в 2009 г. они уступали по численности коллемболам на разных опытных площадках (рис. 3 , В; 4, В). В фоновом сообществе плотность населения мезостигматических клещей статистически не отличалась от плотности населения таких групп, как акаридиевые клещи, коллемболы, личинки двукрылых, и была достоверно ниже плотности населения ведущей группы - панцирных клещей (рис. 2, В).

Diptera (larvae). В первый период наблюдений (2006 г.) личинки двукрылых были одной из многочисленных групп наряду с мезостигматическими клещами в контроле (техническая рекультивация) и на площадке агрохимической обработки как на стадии «низкое проективное покрытие», так и на стадии «высокое проективное по-
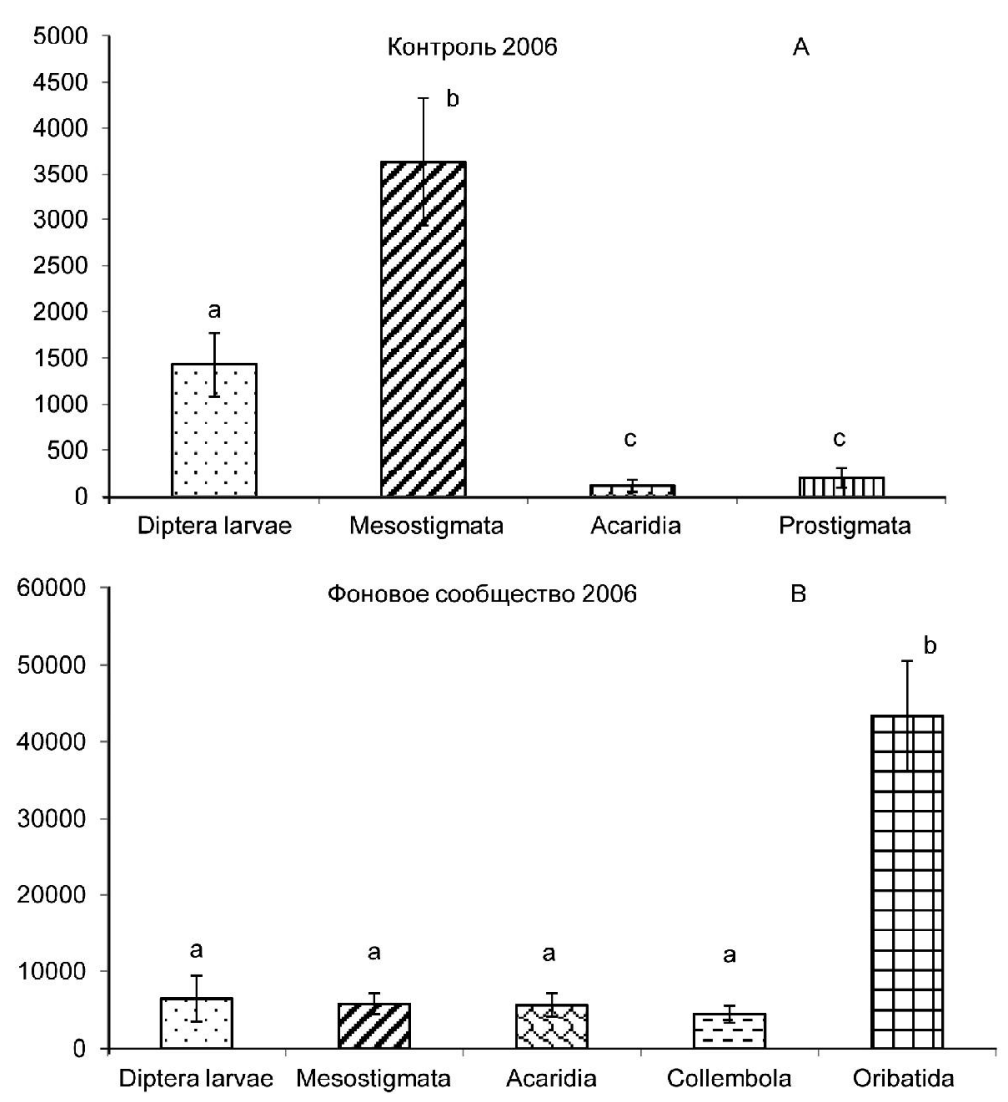

Рис. 2. Плотность населения (экз./М², по вертикали; показана ошибка средней) таксономических групп беспозвоночных на контрольной площадке и в фоновом растительном сообществе через четыре года после рекультивации (буквами a, b, с показана достоверность различий параметра при $\mathrm{p}<0.05)$. крытие», под тимофеевкой (рис. 2, А; 3, А). На стадии сукцессии «без растений» это была преобладающая по обилию группа $(86.3 \%)$. В то же время на площадках с биопрепаратами на стадии «высокое проективное покрытие» они значительно уступали по обилию другим таксонам. Так, на площадке «Родер» под тимофеевкой их доля в структуре населения составляла $4.2 \%$, под двукисточником - 3.1 ; на площадке «Универсал» под тимофеевкой -4.9 , под щучкой дернистой $-2.7 \%$. Через семь лет после начала опыта плотность населения личинок двукрылых значительно снижается, на площадке «Родер» под злаками это одна из малочисленных групп $\left(1800 \pm 439\right.$ экз. $/ \mathrm{M}^{2}$; $28 \%$ ) (рис. 4, В).

Prostigmata. Плотность населения простигматических клещей была нестабильной. В 2006 г. их наибольшее обилие отметено преимущественно на стадии сукцессии «низкое проективное покрытие»: на площадке «Родер» они были самыми многочисленными $(63.2 \% ; 15800.0 \pm 6368.0$ экз. $\left./ \mathrm{M}^{2}\right)$ и входили в группу доминантов наряду с акаридиевыми клещами и личинками двукрылых; были одной из доминирующих групп на площадке «Универсал» $\left(34.9 \% ; 4850 \pm 766.2\right.$ экз. $\left./ \mathrm{M}^{2}\right)$ наряду с мезостигматическими клещами и личинками двукрылых; доминантами - на площадке «агрохимические методы» $(17.1 \% ; 2114.3 \pm$ 1179.8 экз. $\left./ \mathrm{M}^{2}\right)$. На стадии «высокое проективное покрытие» их относительное обилие в структуре группировок снижалось: они были субдоминирующими под тимофеевкой на площадке «Универсал», «Родер" и "агрохимические методы» (8.3, 6.5 и $6.2 \%$ соответственно), при этом их плотность населения была статистически ниже, чем плотность населения наиболее многочисленных групп (рис. 3, А; 4, А, В). Под двукисточником площадки "агрохимические методы" они оставались доминантами $(12.4 \%)$.

В 2009 г. наибольшим обилием Prostigmata отличались на стадии сукцессии "низкое проективное покрытие», как и в 2006 г.: первые по обилию на площадке «Универсал» $(49.8 \%)$, субдоминанты на площадке «агрохимические методы» $(9.5 \%)$, а также на стадии «без растений»: доминанты на площадке «Универсал» $(21.6 \%)$, субдоминанты на площадке «Родер» $(5.9 \%)$. Весьма редко они были субдоминирующими на стадии «высокое проективное покрытие», как это наблюдалось на площадке «Родер" $(9.1 \%)$. Таким образом, наибольшее обилие простигматических клещей в группировках микроартропод было связано с ранними стадиями сукцессии фитоценоза.

Acaridia. Акаридиевые клещи были ведущей группой наряду с Diptera и Me- 
sostigmata в ранний период наблюдений. Так, на площадке «агрохимические методы» в 2006 г. они были одной из многочисленных групп как на стадии «низкое проективное покрытие» (48.8\%), так и на стадии «высокое проективное покрытие» (37\% под двукисточником и 38 \% под тимофеевкой) (рис. 3 , А). На этой же площадке в 2009 г. их относительное обилие оставалось высоким на стадии "низкое проективное покрытие» $(57.9 \%)$ и «без растений» $(19.2 \%)$. В то же время на стадии «высокое проективное покрытие» (2009 г.) их доля в структуре группировки составляла лишь $3.3 \%$ при небольшой плотности населения $\left(120.0 \pm 120.0\right.$ экз. $\left./ \mathrm{m}^{2}\right)$ (рис. 3, В). На площадке «Родер» под злаками в первый период наблюдений их относительное обилие было минимальным (1.3\% под тимофеевкой), тогда как в потве с низким проективным покрытием они были в числе доминантов $(14.8 \%)$. Во второй период наблюдений на более позднем этапе сукцессии фитоценоза площадки «Родер» они не отличались по плотности населения от других немногочисленных таксонов $(\mathrm{p}<0.05)$ (рис. 4, В). На площадке «Универсал" в первый период наблюдений было отмечено высокое обилие Acaridia также и под злаками (44.9\% под щучкой дернистой), их доминирование $(90 \%)$ сохранялось на стадии «высокое проективное покрытие» и в 2009 г.

Collembola. В первый период наблюдений (2006 г.) как в контроле, так и на площадке «агрохимические методы» коллемболы не зарегистрированы (рис. 2, А; рис. 3 , А). Через семь лет после рекультивации (2009 г.) на площадке «агрохимические методы» на стадии «высокое проективное покрытие» коллемболы были доминирующей группой наряду с личинками двукрылых. Плотность их населения статистически отличалась от плотности мезостигматических и акаридиевых клещей (рис. 3, В). На площадке «Родер» под тимофеевкой коллемболы были доминирующей группой наряду с мезостигматическими клещами уже в первый период наблюдений (рис. 4, А). Плотность населения коллембол под тимофеевкой была статистически выше по сравнению с другими таксонами беспозвоночных, хотя при этом наблюдалась сравнительно высокая плотность мезостигматических клещей (рис. 4, А). Во второй период наблюдений под злаками на площадке "Родер" коллемболы были

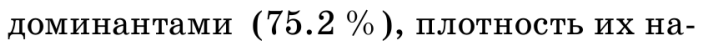
селения была статистически выше, чем всех остальных групп (при $\mathrm{p}<0.05$ ) (рис. 4, B).

На площадке «Универсал» под злаками в первый период наблюдений коллем- болы были весьма малочисленной группой $\mathbf{( 4 . 2} \%$; $400.0 \pm 206.5$ экз. $/ \mathrm{M}^{2}$ под тимофеевкой и $0.5 \%$; $109.1 \pm 77.9$ экз. $/ \mathrm{M}^{2}$ под щучкой дернистой). Во второй период под злаками их обилие возрастало.

Oribatida. Панцирные клещи были доминирующей группой в фоновом сообществе в оба периода наблюдений $\left(66.8 \% ; 43300.0 \pm 7184.0\right.$ экз. $/ \mathrm{m}^{2}$ в 2006 г.; $59.8 \% ; 35600.0 \pm 8663.8$ экз. $/ \mathrm{M}^{2}$ в 2009 г.) Плотность их населения была статистически выше плотности населения всех остальных таксонов (рис. 2, В). Наши данные вполне согласуются с данными других авторов о численности панцирных клещей в арктических и субарктических биоценозах (Seniczak, 1978; Solhoy, 1981; Hagvar, 2009). На опытных площадках в первый период наблюдений орибатиды не обнаружены. Через семь лет после рекультивации (2009 г.) они зарегистрированы на площадках с биопрепаратами, при этом были весьма малочисленны: на стадии «высокое проективное покрытие» $(0.2 \%$; 160.0 экз. $\left./ \mathrm{M}^{2}\right)$ и «низкое проективное покрытие» $\left(0.2 \% ; 200.0\right.$ экз. $\left./ \mathrm{M}^{2}\right)$ площадки «Родер»; на стадии «высокое проективное покрытие" площадки «Универсал» $\left(0.1 \% ; 33.3\right.$ экз. $/$ м $\left.^{2}\right)$. Пионерными видами орибатид были Liochthonius (L.) sellnicki (Thor, 1930) (семейство Brachychthoniidae Thor,
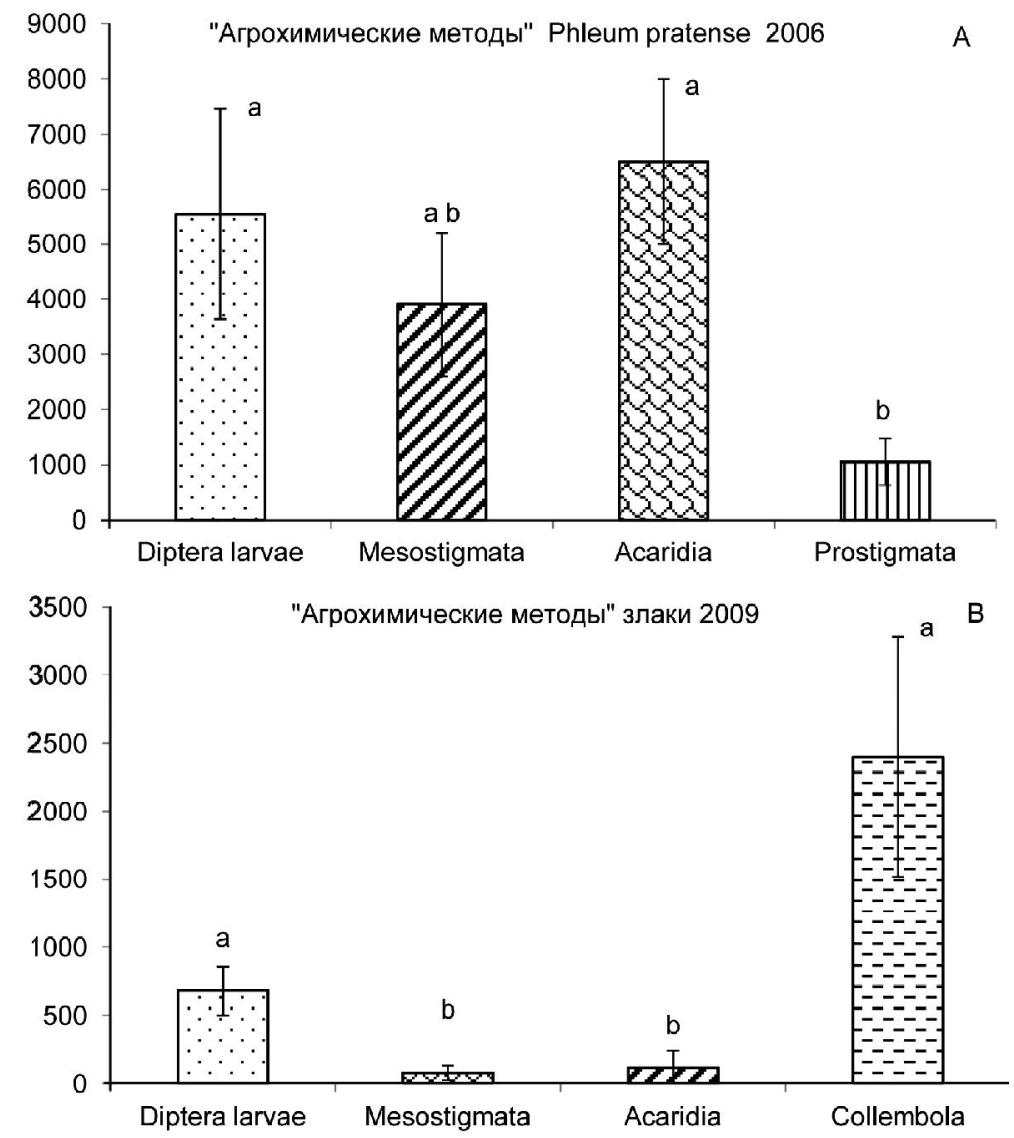

Рис. 3. Плотность населения (экз./М², по вертикали; показана ошибка средней) таксономических групп беспозвоночных на площадке «агрохимические методы» в разные периоды наблюдений (буквами a и b показана достоверность различий параметра при $p<0.05)$. 
1934), Oppiella (O.) nova (Oudemans, 1902) (Oppiidae Sellnick, 1937), Tectocepheus velatus (Michael, 1880) (Tectocepheidae Grandjean, 1954), Oribatula (O.) tibialis (Nicolet, 1855) (Oribatulidae Thor, 1929), Eupelops plicatus (Koch, 1835) (Phenopelopidae Petrunkevitch, 1955). В большинстве своем это эвритопные виды. Для ряда видов (O. поva, L. sellnicki, T. velatus) известно явление партеногенеза, что является адаптивной особенностью при освоении новых субстратов (Гиляров, 1982). Медленные темпы сукцессии панцирных клещей по сравнению с другими таксонами микроартропод были показаны как при нефтяном загрязнении (Артемьева, 1989; Мелехина, 2007, 2012), так и при других типах антропогенных нарушений почвы (Ryabinin, 2009; Microarthropod ..., 2015).

На более поздних стадиях сукцессии фитоценоза разнообразие группировок беспозвоночных повышалось за счет появления новых таксономических групп. Так, на площадке «Родер» под злаками в 2009 г. были отмечены имаго и личинки жуков, личинки перепончатокрылых, сеноеды.

Изменения плотности населения отдельных таксономических групп определяли динамику структуры групиировок беснозвоночных в ходе сукцессии фитоценоза. Через четыре года после рекультивации (2006 г.) на площадке «агрохимические методы» на ранней стадии сукцессии
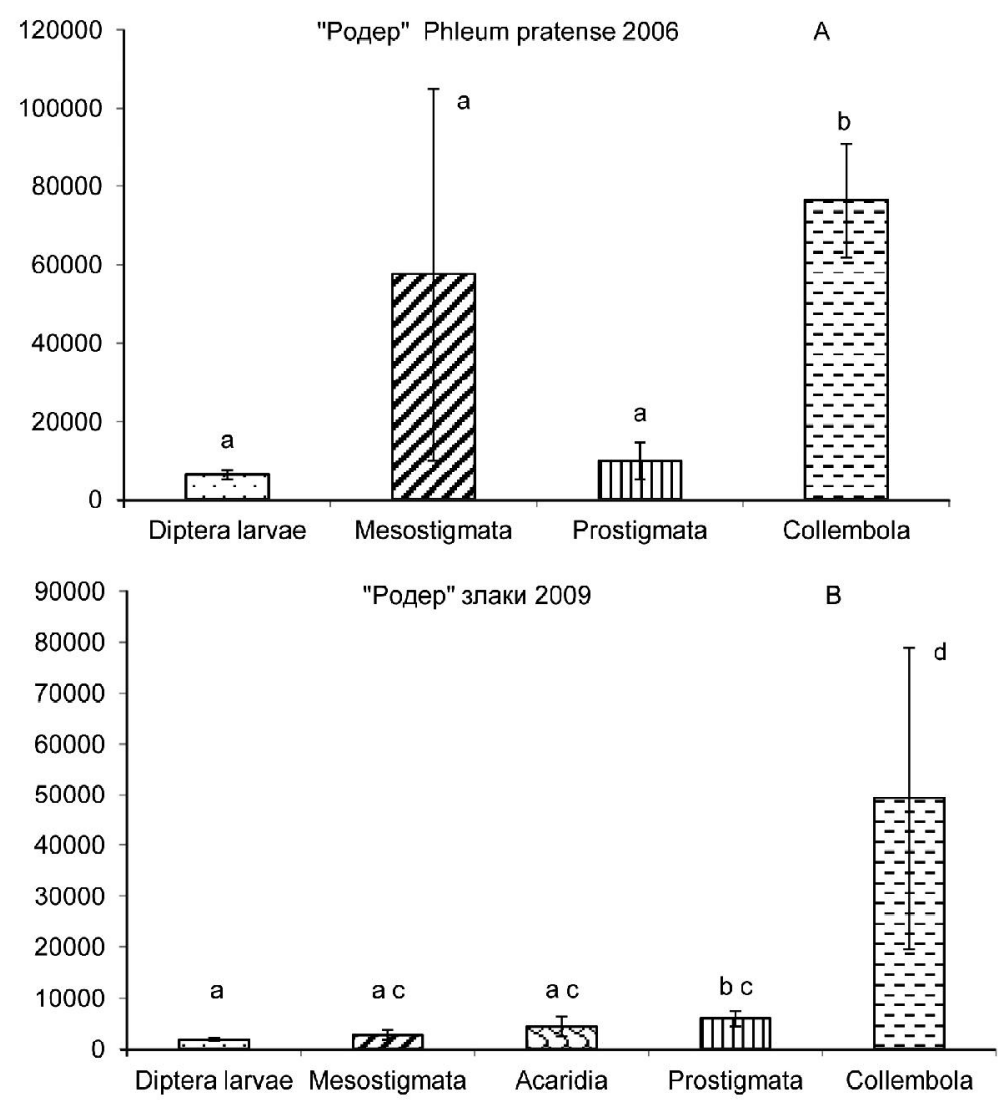

Рис. 4. Плотность населения (экз./ $\mathrm{M}^{2}$, по вертикали; показана ошибка средней) таксономических групп беспозвоночных на площадке «Родер» в разные периоды наблюдений (буквами a, b, c и d показана достоверность различий параметра при р <0.05). («без растений») основу группировки беспозвоночных составляли личинки двукрылых (86.3\%); присутствовали также мезостигматические клещи $(11.8 \%)$. На стадии «низкое проективное покрытие» были представлены клещи различных таксономических групп: Mesostigmata (12.4\%), Acaridia (48.8 \%), Prostigmata (17.1\%). В группу доминантов входили и личинки двукрылых $(20.7 \%)$. Под злаками наиболее многочисленными были мезостигматические (41\% под двукисточником и $22.9 \%$ под тимофеевкой) и акаридиевые (37 и 38 \% соответственно) клещи.

На площадке «Универсал» наибольшая доля личинок двукрылых отмечена на стадиях сукцессии «низкое проективное покрытие» $(12.2 \%)$ и «без растений» $(\mathbf{1 0 . 5} \%)$. Основу населения микроартропод на стадиях «низкое проективное покрытие» и «без растений» составляли мезостигматические клещи (51.7 и $47.1 \%$ соответственно), на стадии "высокое проективное покрытие»-Mesostigmata (76.3 \% под тимофеевкой и $45.6 \%$ под щучкой дернистой) и Acaridia (44.9 \% под щучкой дернистой). Группировки микроартропод на данной площадке характеризовались высоким обилием мезостигматических клещей, а также присутствием коллембол на всех стадиях сукцессии фитоценоза с небольшим относительным обилием. Орибатиды не были найдены. Из сапрофагов наиболее многочисленными были двукрылые.

На стадии "без растений» площадки «Родер» единственной группой беспозвоночных были двукрылые. На стадии «низкое проективное покрытие» подавляющее число экземпляров составляли клещи, главным образом Prostigmata $(63.2 \%)$. Отличительной чертой площадки «Родер» было высокое относительное обилие коллембол под сеяными злаками (стадия «высокое проективное покрытие»); под двукисточником они составляли более $87 \%$ всей группировки, под тимофеевкой - 50 \% . Плотность населения коллембол под двукисточником достигала 220000 экз. $/ \mathrm{M}^{2}$, в то время как в почве фонового участка она составляла 4400 экз. $/$ м $^{2}$ (рис. 2, В). Мезостигматические клещи под тимофеевкой являлись второй доминирующей группой $(37.7 \%)$ наряду с коллемболами. Панцирные клещи не обнаружены.

На контрольной площадке (техническая рекультивация) структура населения микроартропод была сходной с таковой в вариантах «без растений» площадок биорекультивации. По обилию в контроле преобладали мезостигматические клещи (67.2\%).

Через семь лет после рекультивации в структуре группировок произошло перераспределение обилия основных так- 


\section{ВЕСТНИК ИБ КОМИ НЦ УрО РАН 2019 № 1}

сономических групп. Уменьшилась доля участия личинок двукрылых на всех стадиях сукцессии фитоценоза. Также снижалось обилие мезостигматических клещей. Доминирующей группой становились коллемболы с наиболее высоким обилием под сеяными злаками. В составе группировок появились панцирные клещи, которые отмечались на стадии «высокое проективное покрытие» с небольшим обилием. При дальнейшем развитии фитоценоза, постепенном замещении злаков-рекультивантов аборигенными растениями и переходе растительных сообществ из сеяных злаков к сообществам, близким к фоновым, увеличивалось разнообразие и относительное обилие панцирных клещей. В то же время снижалась доля участия других таксономических групп.

Можно заключить, что по мере развития фитоценоза на площадках рекультивации увеличивалась плотность населения беспозвоночных, повышалось их разнообразие. Менялся вклад отдельных таксонов в сложение группировок. На ранней стадии сукцессии («без растений») регистрировали небольшое число таксонов, по обилию преобладали мезостигматические клещи и личинки двукрылых. В ходе сукцессии снижалось относи'ельное обилие хищников - мезостигматических клещей, соответственно, повышалось обилие сапрофагов. На стадии «низкое проективное покрытие» разнообразие группировок повышалось по сравнению со стадией «без растений», заметный вклад в их структуру вносили акаридиевые и простигматические клещи. На стадии «высокое проективное покрытие» ведущей группой становились коллемболы. Панцирные клещи были зарегистрированы на стадии «высокое проективное покрытие» в более поздний период наблюдений - через семь лет после рекультивации. На более поздних стадиях сукцессии наблюдалось повышение разнообразия беспозвоночных за счёт появления новых групп (имаго и личинок жуков, личинок перепончатокрылых). Т.И. Артемьевой (1989) были получены сходные результаты для почв с нефтяным загрязнением: в акарофауне относительно быстро возрастала доля хищных (гамазовых) клещей, а комплекс наиболее типичных сапрофагов - панцирных клещей формировался медленно.

Очевидно, что повышению плотности населения беспозвоночных и возрастанию обилия сапрофагов способствовало накопление растительных остатков, которое наиболее было выражено на участках с высоким проективным покрытием сеяных злаков, и обогащение почвы гумусовыми веществами. Кроме того, развитие корневой системы злаков-рекультивантов способствует аэрации почвы, формированию ее структуры, образованию естественных ходов и полостей, обитателями которых являются беспозвоночные. Отмечалось, что растения ускоряют процессы са- моочищения загрязнённой нефтью почвы, что связано с поступлением продуктов их метаболизма, стимулирующих микробиологическую и ферментативную активность почвы (Природоохранные ..., 2006). Показано, что злаки-рекультиванты наряду с нефтеокисляющими микроорганизмами, принимают участие в процессах биодеградации нефти (Secondary successions ..., 2015).

Т.И. Артемьева (1989) указывала на связь процессов деградации нефти в почве, формирования растительного покрова и животного населения. Автором отмечено, что «сапротрофный комплекс животных формируется вслед за растительным покровом и его особенности определяются характером растительности».

Была установлена связь сукцессии беспозвоночных с формированием растительности на новых субстратах. Так, при зарастании пепловых полей, образовавшихся после извержения вулканов, злаками, осоками, в некоторых местах мхом или бамбуком создавались благоприятные условия для обитания беспозвоночных: увеличивалось количество гумусированных органических остатков в пеплах. С появлением растительности отмечено увеличение разнообразия как микрофлоры, так и микрофауны (Ryabinin, 2009).

При зарастании отвалов каменных карьеров происходило накопление растительного опада, подстилки и корней, начиналась дифференциация почвенного профиля. Отмечено, что на отвалах первого года микроартроподы концентрировались около корней растений. По мере зарастания отвалов травами и деревьями увеличивалась плотность населения панцирных клещей, возрастало число видов и родов, повышалось разнообразие их жизненных форм, распределение становилось более равномерным (Ryabinin, 2009).

\section{Заключение}

Выявлено повышение плотности населения беспозвоночных в ряду сукцессии фитоценоза «без растений» - «низкое проективное покрытие»«высокое проективное покрытие». В ходе сукцессии изменялась плотность населения отдельных таксономических групп, что определяло динамику структуры группировок. На ранней стадии сукцессии фитоценоза (контрольная площадка, выборки «без растений») ведущими таксонами в структуре населения были личинки двукрылых и мезостигматические клещи. На стадии «низкое проективное покрытие» комплексы беспозвоночных дополняли акаридиевые и простигматические клещи, которые могли входить в группы доминантов, наряду с Mesostigmata и Diptera. Таксоны, наиболее многочисленные на ранних стадиях сукцессии фитоценоза, на более поздней стадии ( ввысокое проективное покрытие») уходили из состава доминантов, уступая по обилию коллемболам. Характер динамики обилия кол- 


\section{ВЕСТНИК ИБ КОМИ НЦ УрО РАН 2019 № 1}

лембол отличался на площадках с разными методами рекультивации. На площадках с биопрепаратами под злаками они выходят на уровень доминантов уже в первый период наблюдений. В это же время на площадке «агрохимические методы» коллемболы не были зарегистрированы ни под тимофеевкой, ни под двукисточником. Через семь лет после рекультивации они были доминирующей по обилию группой под злаками как на площадках с биопрепаратами, так и на площадке «агрохимические методы». Панцирные клещи регистрировались на более поздних стадиях сукцессии фитоценоза - «высокое проективное покрытие», иногда "низкое проективное покрытие», в более поздний период наблюдений - через семь лет после рекультивации. Пионерными были эвритопные виды орибатид.

Работа выполнена при частичной финансовой поддержке РФФИ в рамках научного проекта № 18-29. 05028 мк и государственного задания по теле "Распространение, систематика и пространственная орга низация фауны и населения наземных и водных жи вотных таежных и тундровых ландшафтов и әкоси стем европейского северо-востока России» (№ гос. регистрации АААA-A17-117112850235-2).

\section{ЛИТЕРАТУРА}

Артемьева, Т. И. Влияние загрязнения почвы нефтью и нефтепромысловыми сточными водами на комплекс почвенных животных / Т. И. Артемьева, А. К. Жеребцов, Т. М. Борисович // Восстановление нефтезагрязненных почвенных экосистем : сборник научных трудов. - Москва : Наука, 1988. - С. 82-98.

Артемьева, Т. И. Комплексы почвенных животных и вопросы рекультивации техногенных территорий / Т. И. Артемьева. - Москва : Наука, 1989. - 111 с.

Атлас почв Республики Коми / под ред. Г. В. Добровольского, А. И. Таскаева, И. В. Забоевой. - Сыктывкар, 2010. - 356 с.

Атлас Республики Коми по климату и гидрологии. Москва : Дрофа; ДиК, 1997. - 116 с.

Гиляров, М. С. Экологическое значение партеногенеза / М. С. Гиляров // Успехи современной биологии. - 1982. - Т. 93, вып. 1. - С. 10-22.

Животное население как индикатор экологического состояния почв западно-сибирского Севера под влиянием нефтезагрязнений / В. Г. Мордкович, В. С. Андриевский, О. Г. Березина, И. И. Любечанский, И. И. Марченко / / Сибирский экологический журнал. 2004. - № 4. - С. 467-474.

Канев, В. А. Мониторинг динамики восстановления растительности на участках с нефтяным загрязнением при различных методах биологической рекультивации в подзоне крайнесеверной тайги / В. А. Канев // Стационарные исследования лесных и болотных биогеоценозов: экология, продукционный процесс, динамика : тезисы докладов Всероссийской научной конференции с международным участием. - Сыктывкар : Изд-во Коми НЦ УрО РАН, 2016. - С. 67-69.

Леса Республики Коми / под ред. Г. М. Козубова, А. И. Таскаева. - Москва, 1999. - 332 с.

Маркарова, М. Ю. Динамика разнообразия почвенной биоты при восстановлении нефтезагрязненных земель Крайнего Севера как индикационный показатель состояния почвенных экосистем / М. Ю. Маркарова, Е. Н. Мелехина // Международный контактный форум по сохранению местообитаний в Баренцевом регионе : материалы IV совещания. - Сыктывкар, 2006. - C. $135-139$.

Маркарова, М. Ю. Использование углеводородокисляющих бактерий для восстановления нефтезагрязненных земель в условиях Крайнего Севера / М. Ю. Маркарова / автореф. дис. ... канд. биол. наук. - Пермь, 1999. - 22 c.

Маркарова, М. Ю. Опыт применения биопрепарата «Универсал» для рекультивации нефтезагрязненных земель / М. Ю. Маркарова // Вестник Института биологии Коми научного центра Уральского отделения PAH. - 2004. - № 10 (84). - C. 21-23.

Мелехина, E. Н. Влияние нефтяных загрязнений на почвенную микрофауну тундровых сообществ крайнесеверной тайги / Е. Н. Мелехина // Экология человека. - 2007. - № 1. - С. 16-23.

Мелехина, Е. Н. Восстановительные сукцессии микроартропод в почвах с нефтяным загрязнением/ Е. Н. Мелехина // Животные: экология, биология и охрана : материалы Всероссийской научной конференции с международным участием / ред. В. В. Ревин, В. А. Кузнецов, А. А. Андрейчев. - Саранск : Изд-во Мордовского университета, 2012. - С. 250-251.

Методы почвенно-зоологических исследований. Москва : Наука, 1975. - 275 с.

Михеева, В. Л. Сукцессии панцирных клещей (Oribatei) в почвах верховых болот Нижневартовского района / В. Л. Михеева // Вестник Томского государственного университета. - 2008. - № 317. - С. 246-249.

Определение эффективности методов рекультивации загрязненных нефтью почв / E. II. Мелехина, М. Ю. Маркарова, Е. М. Анчугова, Т. Н. Щемелинина, В. А. Канев // Известия Коми научного центра УрО РАН. - 2016. - Вып. 3 (27). - С. 61-70.

Песенко, Ю. А. Принципы и методы количественного анализа в фаунистических исследованиях / Ю. А. Песенко. - Москва, 1982. - 287 с.

Природоохранные работы на предприятиях нефтегазового комплекса. Ч. 1. Рекультивация загрязненных нефтью земель в Усинском районе Республики Коми / Р. В. Маганов, М. Ю. Маркарова [и др.]. Сыктывкар, 2006. - 208 с.

Шилова, И. И. Первичные сукцессии растительности на техногенных песчаных обнажениях в нефтегазодобывающих районах Среднего Приобья / И. И. Шилова // Экология. - 1977. - № 6. - С. 5-15.

Шилова, И. И. Влияние загрязнения нефтью на формирование растительности в условиях техногенных песков нефтегазодобывающих районов Среднего Приобья / И. И. Шилова // Растения и промышленная среда. - Свердловск : Изд-во УрГУ, 1978. - Вып. 5. C. 44-52.

Юдин, Ю. П. Геоботаническое районирование / Ю. П. Юдин // Производительные силы Коми АССР. Москва ; Ленинград : Изд-во АН СССР, 1954. - Т. 3, ч. $1 .-$ C. $323-369$.

Approaches to the Assessment of the Efficiency of Remediation of Oil-Polluted Soils / E. M. Anchugova, E. N. Melekhina, M. Yu. Markarova, T. N. Shchemelinina // Eurasian Soil Science. - 2016. - Vol. 49, N 2. P. 234-237.

Coulson, S. J. Microscale distribution patterns in high Arctic soil microarthropod communities: the influence of plant species within the vegetation mosaic / S. J. Coulson, I. D. Hodkinson, N. R. Webb // Ecography. 2003. - Vol. 26. - P. 801-809.

Hagvar, S. Primary Succession of Soil Mites (Acari) in a Norwegian Glacier Foreland, with Emphasis on Oribatid Species / S. Hagvar, T. Solhoy, C. E. Mong, // Arctic, Antarctic, and Alpine Research. - 2009. - Vol. 41. - N 2. - P. 219-227. 
Hammer, O. PAST: Paleontological Statistics software package for education and data analysis / O. Hammer, D. A. T. Harper, P. D. Ryan // Palaeontologia Electronica. - 2001. - N 4 (1). - 9 p.

Microarthropod communities of industrially disturbed or imported soils in the High Arctic; the abandoned coal mining town of Pyramiden, Svalbard / S. J. Coulson, A. Fjellberg, E. N. Melekhina, A. A. Taskaeva, N. V. Lebedeva, O. A. Belkina, S. Seniczak, A. Seniczak, D. J. Gwiazdowicz // Biodivers. Conserv. - 2015. - Vol. 24, N 7. - P. 1671-1690. - doi: 10.1007/s10531-015-0885-9

Ryabinin, N. A. Successions of Oribatid Mites (Acariformes: Oribatida) on Disturbed areas / N. A. Ryabinin, A. N. Pan'kov // Biology Bulletin. - 2009. - Vol. 36, N 5. - P. 510-515.

Secondary successions of biota in oil-polluted peat soil upon different biological remediation methods / E. N.
Melekhina, M. Yu. Markarova, T. N. Shchemelinina, E. M. Anchugova, V. A. Kanev // Eurasian Soil Science. 2015. - Vol. 48, N 6. - P. 643-653. - doi: 10.1134/ S1064229315060071

Seniczak, S. Structural dependence of moss mite populations (Acari, Oribatei) on patchiness of vegetation in moss/lichen tundra / S. Seniczak, V. Plichta // Pedobiologia. - 1978. - N 18. - P. 145-152.

Solhoy T. Oribatei fauna (Acari) on alpine heath at Kevo, Finland / T. Solhoy, S. Koponen // Reports from the Kevo subarctic research station. - 1981. - Vol. 17, N 1. - P. 41-43.

Subias, L. S. Listado sistematico, sinonimico y biogeografico de los acaros oribatidos (Acariformes: Oribatida) del mundo (excepto fosiles) / L. S. Subias. - Graellsia. 2004. - N 60 (numero extraordinario). - 305 p. - Online version accessed in march 2019, 536 pp.; http:// bba.bioucm.es/cont/docs/RO_1.pdf

\title{
RECOVERY OF SOIL INVERTEBRATES AFTER OIL POLLUTION: IMPORTANCE OF COMPOSITION AND DEVELOPMENT DEGREE OF PLANT COMMUNITY
}

\author{
E. N. Melekhina \\ Institute of Biology of Komi Scientific Centre of the Ural Branch of the Russian Academy of Sciences, Syktyvkar
}

\begin{abstract}
The study was conducted in the European North of Russia, the Usinsk district of the Komi Republic $\left(66^{\circ} 37^{\prime} \mathrm{N}, 57^{\circ} 07^{\prime} \mathrm{E}\right)$. In the field experiment conducted on the territory of oil spill, four sites were examined with different remediation methods: 1 - biological preparation 'Roder', 2 - biological preparation 'Universal', 3 - agrochemical methods, 4 - mechanical cleaning of oil, as well as background plant community. The phytocenosis succession stages differing by the total projective cover (CPC) of herbaceous layer as 'without plants', 'low projective cover' (CPC 30-40\%), 'high projective cover' (CPC 70-80\%) were identified on the experimental sites. At the stage 'high projective cover', we studied groupings of invertebrates under different grass species as as Phleum pratense and Phalaroides arundinacea - at the site 'agrochemical methods', Phleum pratense - at the site 'Roder', Phleum pratense and Deschampsia caespitosa - at the site 'Universal'. The regularities of the soil zoocenosis dynamics during recovery of plant community were determined. The data obtained four and seven years after the start of the experiment were analyzed. The population density of invertebrates increased along with the following phytocenosis succession series as 'without plants' - 'low projective cover' - 'high projective cover' after remediation of oil-polluted peat soil. At the early succession stage ('without plants'), the animal groupings were represented by a small number of taxa; Mesostigmatic mites and Diptera larvae dominated in abundance. At the 'low projective cover' succession stage, microarthropods became diverse. The acaridium and prostigmatic mites appeared in the groupings. At the 'high projective cover' stage, there was a sharp increase in number of springtails which became the dominant group. The oribatid mites were recorded in soil later than the other microfauna groups; their diversity increased at the later phytocenosis development stages, particularly when sown grasses were replaced by native plants.
\end{abstract}

Key words: oil pollution, soil invertebrates, oribatid mites (Oribatida), mesostigmatic mites (Mesostigmata), prostigmatic mites (Prostigmata), acarid mites (Acaridia), springtails (Collembola), Diptera larvae (Diptera), bioremediation, subzone of the extremely-northern taiga 